\title{
Sobre a inconstância da alma cordial: presença e ausência ameríndia em Raízes do Brasil
}

\author{
On the inconstancy of the cordial soul: presence and absence \\ of the Amerindian in Roots of Brazil
}

\author{
André Jobim Martins \\ https://orcid.org/0000-0002-4560-1139 (D)
}

\section{RESUMO:}

Em Raízes do Brasil (1936), Sérgio Buarque de Holanda atribui à cultura ibérica o protagonismo exclusivo na gênese do estilo de vida e pensamento predominante no Brasil, sintetizado na imagem do "homem cordial". Este ensaio argumenta que a cultura ibérica, tal como descrita no livro, não se conforma perfeitamente à dimensão intelectual da cordialidade. O "homem cordial" é reexaminado à luz das reflexões de Eduardo Viveiros de Castro sobre a "inconstância" tupinambá, no sentido de propor que certos traços dessa cultura tornam mais compreensível a análise que Sérgio Buarque faz da mentalidade brasileira. A pertinência da hipótese é demonstrada a partir do realce de mudanças ocorridas no texto entre suas duas primeiras edições (1936 e 1948), relacionadas à caracterização da cultura portuguesa e da sua interação com as culturas ameríndias, e de um exame daquilo que se poderia considerar uma inconstância do intelecto no capítulo "O homem cordial", em cotejo com as leitura que Oswald de Andrade faz de Raízes num ensaio de 1950.

\section{PALAVRAS CHAVE:}

Sérgio Buarque de Holanda; Literatura brasileira; Historiografia brasileira

\section{ABSTRACT:}

In Sérgio Buarque de Holanda's Roots of Brazil (1936), Iberian culture plays an exclusive role in the genesis of the style of life and thought prevalent in Brazil, which is synthetically described in the image of the "cordial man". This essay attempts to show that the description of Iberian culture presented in the book does not conform neatly with the intellectual dimension of cordiality. The "cordial man" is reexamined in the light of the reflections of Eduardo Viveiros de Castro on Tupinamba "inconstancy", aiming to propose that certain traits of Amerindian culture render Sergio Buarque's analysis of an alleged typical Brazilian mentality more comprehensible. The thesis is tentatively demonstrated by highlighting alterations in the text between its first two editions (1936 and 1948), concerning Portuguese culture and its interactions with Amerindian cultures, and by examining what one might call an inconstancy of the intellect in the chapter "The cordial man", in comparison with Oswald de Andrade's 1950 essay on Roots of Brazil.

\section{KEYWORDS:}

Sérgio Buarque de Holanda; Brazilian literature; Brazilian Historiography 
O homem é difícil de descobrir, e descobrir a si mesmo, o mais difícil de tudo; com frequência, o espírito mente acerca da alma

Zaratustra/Nietzsche

\section{Plasticidade e inconstância}

Eduardo Viveiros de Castro abre um conhecido estudo de cosmologia ameríndia (2003) com uma referência ao Sermão do Espírito Santo, onde Antônio Vieira tratava da atitude dos povos originários do litoral brasileiro ante as tentativas, pelos catequistas, de convertê-los ao cristianismo. Vieira ilustra o problema que tinha diante de si por meio do contraste entre duas metáforas que dão título ao ensaio do antropólogo: o mármore e a murta. "A estátua de mármore", imagem de Vieira para a relação do europeu com a fé, "custa muito a fazer pela dureza e resistência da matéria; mas, depois de feita uma vez, não é necessário que the ponham a mão: sempre conserva e sustenta a figura". A fé do índio, por outro lado, é representada pela estátua de murta, "mais fácil de formar, pela facilidade com que se dobram os ramos.

No entanto, esse outro gênero de estatuária anímica oferecia algumas dificuldades ao apostolado. Vieira adverte que "é necessário andar sempre reformando e trabalhando nela, para que se conserve", pois, "se deixa o jardineiro de assistir, em quatro dias sai um ramo que the atravessa os olhos, sai outro que the descompõe as orelhas, saem dois que de cinco dedos fazem sete, e o que antes era um homem, já é uma confusão de murtas". O pregador que viesse ao Brasil com a intenção de conquistar novas almas para a fé cristã tinha diante de si uma tarefa especialmente árdua, pois tinha que estar sempre a postos para impedir que a "nova figura" do índio aparentemente convertido retornasse à "bruteza natural". Era preciso valer-se de uma série de expedientes que auxiliassem na conformação virtuosa dessas almas contumazes no erro: "que lhes corte o que vicejam os olhos, para que creiam o que não veem", "que Ihes cerceie o que vicejam as relhas, para que 
não deem ouvidos às fábulas de seus antepassados", "que thes decepe o que vicejam os pés, para que se abstenham das ações e costumes bárbaros da gentilidade". Somente "trabalhando sempre contra a natureza do tronco e o humor das raízes" é que se lograria conservar nessas "plantas rudes" a forma não natural da crença exclusiva em Cristo (VIEIRA apud VIVEIROS DE CASTRO 2003, p. 183-184).

O fenômeno anotado por Vieira é recorrente nos relatos dos séculos XVI e XVII sobre os tupis da costa: muito espantava os missionários cristãos a acolhida entusiasmada que muitos índios davam à boa nova trazida de além-mar. O otimismo inicial dos evangelizadores era, porém, rapidamente frustrado. Não obstante se submeterem ao batismo e à pregação sem oferecer a resistência que seria de esperar de pagãos, os naturais da terra logo recalcitravam na prática de costumes abomináveis (do ponto de vista do cristianismo, é claro). O requinte da interpretação que Vieira extrai do problema se dá a ver na imagem por ele empregada para ilustrá-lo. Em vez de simplesmente recriminar os brasis por alguma suscetibilidade diabólica, ele lança, bem ao estilo da racionalidade analógica e do gosto barroco pela metáfora engenhosa, a ideia de que o comportamento dos gentios se explica por uma diferença fundamental na sua conformação anímica - mais exatamente, de que as almas dos índios participariam de um sistema de disposições e ritmos vitais "vegetal". Não adiantaria, portanto, esperar delas a rigidez "mineral" atribuída, em contraste, à psicologia europeia.

A essa admirável metáfora se vêm somar, como lastro documental do estudo etnológico de Viveiros de Castro, os eloquentes testemunhos de Anchieta, Gandavo, Nóbrega, Thevet, Abbeville, Évreux, Léry e outros, cujos graus de simpatia para com o gentio variam bastante. São unânimes, porém, em anotar o que se poderia chamar sua motilidade espiritual. O interesse do antropólogo não é, evidentemente, o mesmo dos missionários. Como puderam os tupinambás acolher, com sincero entusiasmo, a teologia e a cosmologia 
do invasor? Como compreender o "mecanismo" de uma tal cultura, que incorporava as ideias do inimigo e os convertia em valor positivo? (VIVEIROS DE CASTRO 2003, p. 194-195)

No presente ensaio, o problema já é outro. Nas páginas seguintes, tentarei esmiuçar aquilo que parece ser uma coincidência, talvez não fortuita, entre a inconstância narrada nos primeiros relatos da colônia e uma outra, que aparece num livro bem posterior ao desencontro em que nossa mitologia nacional ambienta a origem do que viria a ser o Brasil. É num dos chamados "ensaios de interpretação nacional", Raízes do Brasil, de Sergio Buarque de Holanda (1936), que encontraremos algo que se poderia chamar de uma segunda inconstância, ou pelo menos a descrição de uma forma de pensamento (o "homem cordial") que encontra algumas coincidências - mais precisamente, o que me parece ser uma analogia estrutural - com aquela mentalidade analisada por Eduardo Viveiros de Castro em "O mármore e a murta". A investigação se ocupa, portanto, de demonstrar como essa chave de leitura, já antecipada muito sucintamente num texto de Oswald de Andrade (1990b), oferece uma perspectiva fecunda para a interpretação de alguns dos aspectos menos compreensíveis do clássico de 1936. Em paralelo, gostaria de propor a hipótese de que há uma conexão mais do que casual entre a "inconstância" ameríndia e a "cordialidade", sem qualquer pretensão de comprovação documental, mas defendendo sua viabilidade para além de um exercício puramente imaginativo. Desde já, é preciso esclarecer que essa linha de leitura vai contra a intencionalidade da argumentação de Raízes do Brasil. Mesmo assim, ela me pareceu suficientemente plausível, e vai tentativamente ensaiada nas páginas que se seguem.

Adentremos no problema de forma algo lateral, o que em tempo se mostrará, espero, justificado pelo rendimento analítico resultante: vejamos como Raízes do Brasil aparece no ensaio "O mármore e a Murta". Sérgio Buarque de Holanda é apresentado pelo antropólogo como um dos intérpretes "mais politicamente corretos" do Brasil, fechando uma série de 
referências a descrições do índio na historiografia nacional, até ali composta de autores mais controversos do ponto de vista de sua recepção contemporânea - o "reacionário" Varnhagen e o "racialista" Gilberto Freyre (VIVEIROS DE CASTRO 2003, p. 185-187). Os antigos moradores da terra, lemos no trecho de Raízes ali citado, "dificilmente se acomodavam [...] ao trabalho metódico e acurado que exige a exploração dos canaviais", pois "sua tendência espontânea era para atividades menos sedentárias e que pudessem exercer-se sem regularidade forçada e sem vigilância e fiscalização de estranhos". Existiria um desencontro fundamental entre as suas disposições espirituais e a lógica do trabalho já então, presume-se, instituída na Europa: "[v]ersáteis ao extremo, eram-Ihes inacessíveis certas noções de ordem, constância e exatidão, que no europeu formam como que uma segunda natureza e parecem requisitos fundamentais da existência da sociedade civil" (HOLANDA apud VIVEIROS DE CASTRO 2003, p. 187).

Como se pode ver no trecho citado, Raízes do Brasil é mobilizado por Viveiros de Castro como caso exemplar para demonstrar a continuada presença da tópica do gentio inconstante em nossa literatura.

A edição citada de Raízes do Brasil é a terceira (1956), mas o antropólogo empregou, na chamada para a referência bibliográfica, o ano da primeira edição (1936). Parece mesmo adequado que assim tenha sido, já que "O mármore e a murta" se vale extensamente de transcrições modernas de textos quinhentistas - o que, respeitada a notação normalmente usada, poderia causar alguma estranheza (pense-se em "Anchieta 1970 " etc). Ocorre, porém, que o trecho citado não se encontra na edição de 1936, mas foi inserido na segunda edição, datada de 1948 - o tema dos cortes e inserções realizados nas edições de 1948 e 1956 vem animando, por sinal, muito da reflexão recente sobre Raízes do Brasil.

Devo advertir que a comparação entre as duas edições feita aqui será restrita aos trechos que tratam das semelhanças e diferenças entre as mentalidades portuguesa e ameríndia 
e deixa de lado, portanto, a discussão mais frequentada na fortuna crítica recente, relativa à situação de Raízes no espectro político brasileiro dos anos 1930 e das ambiguidades do livro no que diz respeito à alternativa que então se apresentava entre a democracia liberal e variadas formas de autoritarismo, incluindo o fascismo. Entre os muitos trabalhos de qualidade a esse respeito, vale a pena conferir os de João Kennedy Eugênio (2010), Leopoldo Waizbort (2011), Luiz Feldman (2015), Sérgio da Mata (2016) e Robert Wegner (2016a), além da introdução da edição crítica de Raízes do Brasil por Pedro Meira Monteiro e Lilia Schwarcz (2016). No mesmo volume, podem-se ler, com proveito, alguns textos mais curtos, que em conjunto oferecem uma boa noção do estado da arte na fortuna crítica (em especial, BASTOS 2016; BOTELHO, BRASIL Jr. 2016; CASTRO 2016; MELO 2016; WEGNER 2016b). Não há aqui qualquer pretensão de sintetizar o teor e a orientação das mudanças entre as edições, mas tão somente de mostrar como algumas alterações pontuais dão a ver o aspecto problemático da contribuição do indígena (ou sua ausência) à gênese do homem cordial. Retornemos, pois, ao tema do papel desempenhado pelas culturas ameríndias na economia argumentativa de Raízes.

A ausência do excerto citado em "O mármore e a murta" na primeira edição não teria maior importância para os efeitos do presente estudo, não fosse o teor de parte do trecho que ficava exatamente em seu lugar, e que nas edições subsequentes fica parcialmente excluído e desmembrado em várias páginas, perdendo, assim, boa medida de seu efeito. "Não é certo", lemos na versão de 1936, "que a forma particular assumida pelo grande domínio agrícola fosse uma espécie de manipulação original, fruto de uma vontade criadora e um pouco arbitrária". Ela já teria vindo "pronta e acabada" de Portugal. Aqui chegada, ela "apenas se apurou devido a condições peculiares como a abundância de terras, a escassez dos gêneros, a necessidade de vigilância contínua contra o inimigo [o índio]". No sertão inculto, o comportamento dos portugueses fazia algumas concessões ao meio: "Nos campos e florestas, quando à caça ao 
índio ou em busca de pedras e metais preciosos, esses mesmos homens abriam picadas como os naturais da terra e, como eles, construíam canoas de cascas de árvore para vencerem os rios". Esse temperamento contemporizador e plástico ganha, no mesmo trecho, um relevo especial na descrição dos colonos, retratados como "instrumentos passivos, sobretudo, aclimatavam-se facilmente, aceitando o que Ihes sugeria o ambiente, sem cuidar de impor-lhe normas fixas e indeléveis". A mentalidade que dava o tom da empresa colonial portuguesa era a do esforço mínimo: saber "repetir bem o que estava feito ou o que Ihes ensinara a rotina", não tendo "exigências mentais muito grandes". Eram avessos, assim, a todo tipo construção mental sistemática que se costuma associar ao racionalismo, mesmo aquelas inspiradas pela teologia cristã, pois "o Céu parecia-Ihes uma realidade excessivamente espiritual, remota, póstuma, para interferir nos seus negócios de todos os dias" (HOLANDA 1936, p. 26-27).

Os trechos das respectivas edições aqui reproduzidos constam do segundo capítulo de Raízes, intitulado "Trabalho \& Aventura", no qual são atribuídos aos portugueses dois traços culturais que teriam marcado a colonização do Brasil e que são retomados, ainda que implicitamente, na caracterização do "homem cordial", no quinto capítulo: em primeiro lugar, uma ética da aventura, por oposição a uma ética do trabalho; em segundo lugar, uma excepcional plasticidade social, que teria possibilitado a pronta acomodação dos colonos ao trópico mediante alguns compromissos com técnicas e padrões de conduta indígenas. Esse segundo traço explicaria o que o livro entende como a vantagem dos portugueses em relação a outras nacionalidades europeias na colonização de regiões tropicais - e aqui Sérgio Buarque retoma, se não nos conteúdos específicos, ao menos num plano formal, um dos principais argumentos de Casa-Grande \& Senzala, como se pode verificar nas páginas iniciais da primeira edição do livro de Gilberto Freyre (1933). "O sistema patriarcal", escreve Freyre, se caracterizava pela "plástica contemporização" entre a adaptação ao "meio físico e principalmente bioquímico" e a 
imposição de "formas e acessórios estranhos de cultura, que [...] permitem [ao colonizador] conservar-se o mais possível como raça ou cultura exótica" (FREYRE 2006, p. 35).

Ora, a passagem anteriormente citada de Raízes, descaracterizada pela segunda edição, destaca a dita plasticidade lusa. Aquela que se lê em "O mármore e a murta", acrescentada ao texto na revisão de 1948, é frontalmente oposta a essa linha de argumentação. Nela, modificam-se os valores e as posições relativas assumidas pelo índio e pelo adventício. O português, no trecho de 1936, é criatura em geral passiva, facilmente adaptável aos usos indígenas quando esses Ihe pareçam poupar esforços, não impondo a seu dia a dia "exigências mentais muito grandes". No adendo de 1948, ele segue aventureiro e avesso ao trabalho, mas ganha a "segunda natureza" de "certas noções de ordem, constância e exatidão" absolutamente "inacessíveis" aos índios.

A mudança é intrigante, quando nada porque justamente aquilo que, na primeira versão, ia confirmar uma congenialidade entre colonizador e indígena é atenuado, por meio de exclusões, redistribuições e adendos, pelo registro de um contraste entre os dois. Mas isso não é tudo: esse novo elemento é criado mediante a inversão de um valor atribuído ao português. A plasticidade, combinada com a sugestão complementar de passividade, passa a ser temperada por um senso abstrato e intervencionista de ordem, "como que uma segunda natureza", exatamente onde antes se notava a ausência do gosto pela imposição de "normas fixas e indeléveis" ao ambiente. Ao mesmo tempo, a redação do adendo tende a tornar apanágio do índio um traço inicialmente comum a ambos, agora intensificado (especifica-se o estilo de conduta indígena como sendo altamente versátil, produzido por estímulos externos, sem opor resistência às contingências do mundo). Convém ainda lembrar a epígrafe do capítulo na primeira edição, da autoria de Salústio, cuja posterior exclusão não é de modo algum casual, pois acompanha a tendência de criar uma separação mais nítida entre as duas culturas: Hi posquam in 
una mœnia convenere, dispari genere, dissimili língua, alius alio more viventes, incredible memoratu est quam facile coaluerint ["É incrível dizer-se como, depois que os reuniu uma única muralha, tão facilmente se ligaram, sendo de raça diferente, de língua diversa e vivendo cada um a seu modo"].

As mudanças integram uma revisão de argumentos bastante abrangente realizada na segunda edição. Se restringirmos o foco da comparação ao tema das relações entre português e índio, notaremos que as alterações tendem a corrigir um tom em geral naturalizador da violência com a qual o português lidou com o índio na conquista, dar maior destaque às contribuições (quase exclusivamente técnicas, segundo lemos) da cultura indígena ao quadro cultural da colônia e, sobretudo, como revela o cotejo entre as passagens citadas e a exclusão da epígrafe, acentuar as diferenças de mentalidade entre adventício e gentio. Para tanto, foi necessário contrariar ou atenuar alguns postulados da primeira edição: o gentio precisou se tornar mais avesso ao trabalho do que o português, e este, menos acomodatício, mais ordeiro e mais "europeu". Essa retificação vai de par, aliás, com a tendência geral da trajetória de Sérgio Buarque ao progressivo incremento no interesse pelas contribuições indígenas à cultura brasileira, restringindo, porém, essa influência a elementos técnico-materiais, ${ }^{1}$ como é notável em suas obras dedicadas à expansão paulista, principalmente Monções (1945) e Caminhos e fronteiras (1957).

Mesmo nesse âmbito restrito, o compromisso do invasor é limitado. É célebre entre os leitores de Sérgio Buarque a metáfora empregada no prefácio de Monções para ilustrar o modo da adaptação dos colonos ao sertão hostil na expansão para o oeste. As formas de vida adventícias teriam logrado acomodar-se ao novo meio por possuírem "a consistência do couro ou do bronze, dobrando-se, ajustando-se, amoldandose a todas as asperezas do meio" (HOLANDA 2014, p. 43). A imagem sugere, de um lado, flexibilidade, mas também uma tenacidade que preserva a integridade da forma. Em Caminhos e fronteiras, são numerosas as observações lançadas para restringir a adoção de técnicas indígenas à "cultura material", 
salientando o caráter racional-utilitário e contingencial dessas apropriações (ver, p. ex., HOLANDA 2017, p. 17, 73-74, 182184, 207-208, 299; BLAJ 1998, p. 48). É verdade que Sérgio Buarque chega a aventar a hipótese de a transculturação envolver até certas práticas religiosas (HOLANDA 2017, p. 109) e a mencionar a persistência do bilinguismo portuguêstupi entre os colonos (HOLANDA 2017, p. 189), mas nada há que chegue a comprometer o "sistema" de "forças seletivas" com que a "sociedade" (ou cultura adventícia) preservava sua "unidade orgânica" (HOLANDA 2017, p. 67), como nota Sérgio no parágrafo inicial do capítulo intitulado "Iguarias de bugre". Esse parágrafo, aliás, é um dos raros momentos de maior pendor teorizante desse livro, quase sempre marcado por uma sobriedade narrativa normalmente associada ao historicismo.

Se nos voltarmos para "O homem cordial", capítulo que fornece o núcleo conceitual da interpretação do Brasil ensaiada em Raízes, não encontraremos um tratamento sistemático das diferenças entre culturas nativas e a adventícia - mesmo porque, a essa altura da narrativa, o índio, desde o início (especialmente na primeira edição) um minguado coadjuvante, saiu de cena. Não há nenhuma indicação, ao menos na versão de 1936, de que a plasticidade, noção importante na construção conceitual do "homem cordial", se restrinja ao âmbito da técnica e da vida material, mesmo porque é ela que irá possibilitar a adaptação de conteúdos culturais no plano dos axiomas da ação social e das representações mentais - é o que verificamos na discussão da Península Ibérica como uma zona de fronteira no primeiro capítulo, intitulado "Fronteiras da Europa". Espanha e Portugal já seriam, antes da expansão ultramarina, "territórios-ponte" que mediavam o contato da Europa com "outros mundos", uma "zona fronteiriça, de transição, menos carregada [...] desse europeísmo" que preservariam, ainda assim, "como patrimônio" (HOLANDA 1936, p. 4).

Aparece nesse primeiro capítulo a tese de que os povos hispânicos dificilmente teriam alcançado os requisitos mínimos necessários à fundação de um corpo político moderno, caso 
tivessem simplesmente conduzido seus negócios segundo as predisposições próprias de sua cultura. Portugueses e espanhóis eram, lemos no primeiro capítulo de Raízes, personalistas, avessos a qualquer noção de autoridade e alheios à doutrina calvinista da predestinação que, no Norte da Europa, contribuía para a espontânea edificação e racionalização de instituições. "É compreensível", lemos, "que jamais se tenha naturalizado entre a gente hispânica a moderna religião do trabalho e o culto à atividade utilitária". À "carência dessa moral do trabalho" correspondia uma "pequena capacidade de organização social". A essa "autarquia do indivíduo", "paixão fundamental" que "não tolera compromissos", só haveria uma alternativa: "a negação e a renúncia a essa mesma personalidade em vista de um bem maior" (HOLANDA 1936, p. 13-14); daí que a virtude "cívica" por excelência fosse, entre os lusos, a obediência. Somente a ação sistemática de forças estranhas ao indivíduo (e eventualmente ao mecanismo cultural local) levaria a uma (precária) conformação do estilo de vida local às formas institucionais e padrões de conduta política modernos. Uma das mais importantes entre essas forças externas teria sido a Companhia de Jesus:

Foram ainda os jesuítas que representaram, melhor de [sic] que ninguém, esse princípio da disciplina pela obediência. Mesmo em nossa América do Sul, eles deixaram disso um exemplo memorável com suas antigas reduções. Nenhum ditador moderno, nenhum teórico do comunismo ou do Estado totalitário, chegou sequer a vislumbrar a possibilidade desse prodígio de racionalização que puderam conseguir os padres da Companhia de Jesus em suas missões. (HOLANDA 1936, p. 14-15)

O tom hiperbólico deixa claro o papel dos jesuítas na tese que se quer avançar: trata-se de um elemento intervencionista que garante um mínimo de racionalidade a um aparato administrativo que, em sua ausência, praticamente não existiria como tal. Mas sua ação é eficaz, sobretudo porque a cultura ibérica oferece, em sua valorização da obediência como fim em si, uma abertura para esse estímulo à organização. 
É logo em seguida que vem à tona, no texto, o esquema morfológico da cultura, que está no centro da arquitetura teórica de Raízes do Brasil, e que estabelece os limites formais da plasticidade:

A experiência e a tradição ensinam que toda cultura só absorve, assimila e elabora verdadeiramente os traços de outras culturas, quando estes encontram uma possibilidade de ajuste aos seus quadros de vida. Nesse particular cumpre lembrar o que se deu com as culturas europeias transportadas ao Novo Mundo. Nem o contato e a mistura com as raças aborígenes fizeram-nos tão diferentes de nossos avós de além-mar como gostaríamos de sê-lo. No caso brasileiro, a verdade, por menos sedutora que possa parecer [a] alguns de nossos patriotas, é que ainda nos associa à Península Ibérica, e a Portugal especialmente, uma tradição longa e viva, bastante viva para nutrir até hoje uma alma comum [...]. Podemos dizer que de lá veio a forma atual de nossa cultura; o resto foi matéria plástica, que se sujeitou bem ou mal a essa forma. (HOLANDA 1936, p. 15)

O trecho, que será mantido nas edições subsequentes, é sem dúvida um dos mais importantes do livro. É do português a primazia na gênese da cultura nacional no plano da forma, funcionalmente superior no modelo de compreensão sociológica levado a cabo. Fica admitida, no entanto, a eventual assimilação de conteúdos plásticos. O arcabouço teórico aqui aludido parece provir de Georg Simmel (Cf., por exemplo, 1971) e, talvez indiretamente, Nietzsche (2003, p. 7-17) em ambos os casos, é razoável supor, com algum intermédio de Gilberto Freyre, embora Sérgio Buarque se empenhe, a partir da década de 1940, em se distanciar do pensamento do sociólogo pernambucano, inclusive diminuindo o peso das referências a Casa-Grande \& Senzala na segunda edição de Raízes. Convém lembrar aqui que uma divergência sobre a leitura que Freyre faz das noções de forma e conteúdo em Simmel é precisamente o objeto de uma resenha mordaz que Sérgio escreve pouco depois do aparecimento da segunda edição de Sobrados e Mucambos (1951) (HOLANDA 1979, p. 99-110). ${ }^{2}$ Note-se, aliás, que a ideia básica aí contida,
2 - Ver também, a respeito dos diálogos e tensões entre Raízes do Brasil e a obra de Gilberto Freyre, Monteiro (2015), Bastos (2005) e Araújo (2000). 
da subordinação do "conteúdo" à "forma" cultural, também preside o modo como Monções e Caminhos e fronteiras compreendem a transculturação entre colonos e nativos.

Parece descabida, à luz da passagem supracitada, portanto, uma leitura como a que Oswald de Andrade (1990b) faz de Raízes num de seus últimos ensaios, aproximando o "homem cordial" à noção de sociedade "primitiva" e "matriarcal". "Pode-se chamar de alteridade", escrevia o autor do Manifesto antropófago, "ao sentimento do outro, isto é, de ver-se o outro em si, de constatar-se em si o desastre, a mortificação ou a alegria do outro". O sentido que ali se atribuía à noção de alteridade, ele sublinhava, era completamente oposto àquele em que o mesmo termo era empregado em certo "vocabulário existencial" disseminado por Charles Baudelaire, que procurava dar expressão ao "sentimento de ser outro, diferente, isolado e contrário". A acepção empregada por Oswald se definia, por outro lado, justamente por uma forma de individualidade que se atualizava na vivência através de um outro, e que no Brasil ganhava corpo como "um dos sinais remanescentes da cultura matriarcal" (ANDRADE 1990b, p. 157). Pretendendo se basear em Raízes do Brasil (citado na segunda edição) e em relatos de cronistas coloniais, o autor propunha um vínculo sociogenético entre a sociabilidade matriarcal e a cordialidade:

No contraponto agressividade-cordialidade, se define o primitivo em Weltanschauung. A cultura matriarcal produz esse duplo aspecto. [...] Compreende a vida como devoração e a simboliza no rito antropofágico, que é comunhão. [...] De outro lado a devoração traz em si a imanência do perigo. E produz a solidariedade social que se define em alteridade. A periculosidade do mundo, a conviç̧ão da ausência de qualquer socorro supraterreno, produz o "Homem cordial", que é o primitivo, bem como as suas derivações no Brasil. (ANDRADE 1990b, p. 159)

O argumento anteriormente reproduzido, por certo desconcertante do ponto de vista das leituras mais convencionais de Raízes, deve ser considerado em sua conexão com um texto mais longo do mesmo autor, redigido, ao que tudo indica, à 
mesma altura que o excerto que acabamos de ler. Trata-se de "A crise da filosofia messiânica", tese elaborada por Oswald de Andrade para concurso da Faculdade de Filosofia da USP em 1950 (ANDRADE 1990a). Ali, Oswald realiza como que uma breve história revisionista do pensamento ocidental (de forte pendor sociologizante), na qual a tradição é lida sob o prisma do modo de organização social "patriarcal" (leia-se, fundado no direito paterno e na servidão entre os homens). Assim, a filosofia teria se ocupado durante séculos em elaborar formulações cada vez mais sofisticadas do "messianismo", termo usado pelo autor para qualificar toda visão de mundo que, oferecendo algum tipo de recompensa em "outro mundo", aplaca a contestação do estado de coisas patriarcal. Nesse grande quadro, o autor chega a incluir cosmovisões estranhas ao ocidente, como o confucionismo, o hinduísmo e o budismo. Segundo Oswald, o messianismo estaria, naquela conjuntura histórica (1950), dando mostras de esgotamento, de modo que o mundo estaria diante da possibilidade da transição do mundo patriarcal, antítese do mundo primitivo e matriarcal, para a era do homem primitivo tecnizado, que desempenha o papel de síntese no esquema dialético orientador da história da filosofia proposta na tese (1990a, p. 103).

Apesar de não haver referência ostensiva a Raízes do Brasil no corpo do texto, não é difícil imaginar, conhecendo a interpretação que o autor fazia da cordialidade, por que o livro de Sérgio Buarque consta da bibliografia de "A crise da Filosofia messiânica". Faz sentido, ao menos num plano formal, associar a cordialidade ao matriarcado, tal como apresentado em "A crise da filosofia messiânica", na medida em que esse tipo de sociedade se caracteriza pela ausência de uma noção de pessoa construída por meio do contraste com o mundo social exterior; pelo contrário, a personalidade do homem "matriarcal" se constrói por meio da internalização do meio social ao qual pertence (ou seja, por um devir na "alteridade") (1990a, p. 143). Não é surpreendente, portanto, que o "homem cordial" compareça ali, implicitamente, e ostensivamente no ensaio mais curto (1990b), como exemplo de sobrevivência 
contemporânea de um traço da cultura matriarcal. Uma chave de leitura que enfatizasse o pensamento ameríndio permitia a Oswald entrever à sua volta alguns contornos daquele estágio de "síntese" histórica, no qual o homem civilizado daria lugar ao "primitivo tecnizado". O caráter inconclusivo e problemático da modernização brasileira não representaria aí um entrave, mas uma oportunidade única, na qual um substrato espiritual ameríndio poderia ser de grande valia para a criação de um estilo de pensamento e uma visão de mundo bem conformadas com aquilo que Oswald imaginava como a humanidade do futuro. Vale notar aqui que essa apropriação nada tem a ver com qualquer exaltação ufanista de algum "caráter nacional", mas participa de uma performance retórica de negação radical do quadro de referências construído pela racionalidade colonial (Cf. RODRIGUES 2013).

Ocorre que não há em momento algum, na argumentação de Raízes, como vimos, a proposição de um vínculo sociogenético entre a cordialidade e a cultura ameríndia. Para quem considere a fidelidade à intenção autoral como cláusula pétrea na interpretação de textos, a leitura não se sustenta em absoluto (é de se perguntar se Sérgio Buarque teria conhecido esse texto ${ }^{3}$, único na vasta fortuna crítica de Raízes), uma vez que toda a evolução argumentativa do livro, não custa repetir, tem por pressuposto o protagonismo do português no processo histórico no qual se forma a cultura brasileira, ela própria não muito distante da portuguesa. Mesmo assim, é apreciável a convergência entre a descrição do homem cordial e as características atribuídas ao homem primitivo por Oswald.

Assim, parece haver algum interesse em verificar se a hipótese de uma influência ameríndia na origem da cordialidade não é, de algum modo, a despeito da intenção de Sérgio Buarque, respaldada no texto de Raízes. Seria o caso, então, de verificar se a argumentação de Raízes efetivamente se circunscreve estritamente dentro das balizas apresentadas no parágrafochave no qual aparece o esquema morfológico da cultura, com o predomínio português no plano formal. Parece haver um

\begin{abstract}
3 - É provável que sim, uma vez que o texto de Oswald de Andrade foi publicado pela primeira vez nos anais do Congresso Brasileiro de Filosofia de 1950. É difícil que ele tivesse escapado à atenção de Sérgio Buarque, que demonstra conhecer pelo menos alguns dos textos então apresentados no ensaio autobiográfico que abre Tentativas de mitologia (HOLAN$D A$ 1979, p. 32-33).
\end{abstract}


delta, um excedente, com relação à cultura portuguesa, que faz do homem cordial mais que um mero sucedâneo do homem ibérico, mesmo quando se leve em conta a apropriação de novos elementos como "matéria plástica" - o que quero propor aqui é que há um salto qualitativo de caráter morfológico. O conteúdo dessa diferença, se assim for permitido dispor os termos, me parece coincidir de forma espantosa, não apenas com a leitura de Oswald, mas com as teses apresentadas em "O mármore e a murta" para explicar a dita inconstância dos tupinambás - a ponto de essa coincidência poder ser considerada, e aqui especulo, sem poder oferecer provas cabais, uma analogia estrutural remissível a uma origem comum. Resta fazer um ensaio de demonstração, verificando se ele resiste a um exame das passagens pertinentes no interior do texto de Raízes. Passemos, então, a um sobrevoo dos principais argumentos que culminarão no "homem cordial". Neste momento devo lembrar que, nessa abordagem, as comparações entre índios e portugueses citadas até o momento são até dispensáveis, o que apenas viria confirmar, aparentemente, um veredicto de disparate sobre a leitura de Oswald.

\section{Raízes insuspeitadas}

A exposição segue, grosso modo, a ordem em que os trechos discutidos aparecem na primeira edição de Raízes do Brasil.

No segundo capítulo, fechando uma passagem longa na qual são acentuadas as diferenças entre holandeses e portugueses, a noção da plasticidade portuguesa é retomada e intensificada pela curiosa afirmação da contiguidade entre a cultura adventícia e o "mundo", aqui entendido como natureza e cultura em sua configuração pré-colonial, consolidando uma tendência que já se verificava na passagem onde líamos sobre a índole acomodatícia dos portugueses: 
[O] generoso empenho [do holandês] em fazer do Brasil uma extensão tropical da pátria europeia sucumbiu desastrosamente, ante a inaptidão que mostraram para fundar a prosperidade da terra nas bases que Ihe seriam naturais, como, bem ou mal, já tinham feito os portugueses. Segundo todas as aparências, o êxito destes resultou justamente de não terem sabido ou podido manter a própria distinção com o mundo que vinham povoar. Sua fraqueza foi sua força. (HOLANDA 1936, p. 36-37)

Esse gênio de contiguidade das formas culturais invasoras com o "meio" (fraqueza que se converte em força) será reafirmado quando, numa discussão sobre os centros urbanos da América Portuguesa, desponta a principal característica que distingue o português do espanhol na narrativa: enquanto este se empenha em imprimir ao esquema urbanístico de suas cidades um sentido de racionalidade, abstração e supremacia do espírito sobre a natureza, com ruas de traçados retilíneos dispostas em planos quadrangulares; a atitude portuguesa na construção de seus centros administrativos se caracteriza pela falta de qualquer planejamento ou vontade, acomodando-se a toda contingência imposta pelo meio ambiente. A cidade portuguesa "não chega a contradizer o quadro da natureza, e sua silhueta confunde-se com a linha da paisagem". O "desalinho" com que as casas são "semeadas", sem "nenhum rigor, nenhum método", "se exprime bem na palavra 'desleixo"'. Curiosamente, é uma sensibilidade telúrica, que antes esperaríamos ver atribuída aos indígenas, que parece resguardar os portugueses do malogro de sua empresa colonial: "se frequentemente acertavam [na escolha dos sítios], devem-no mais ao seu engenho natural [...] do que à ciência que ensinam os livros" (HOLANDA 1963, p. 62-63).

Trata-se aqui, recordarão os leitores de Raízes, da dinâmica contrastante que a partir da segunda edição será ilustrada pelas figuras do "semeador" e do "ladrilhador". O contraponto moderador ao desleixo lusitano vem, outra vez, dos jesuítas, "únicos portadores de uma organização que se orientava segundo um espírito positivamente construtor" (HOLANDA 1936, p. 65). O ponto alto da contemporização do colonizador com o "mundo", por outro lado, se dá na discussão de sua relação com os indígenas: 
Confundindo-se com o gentio principal da costa, cujas terras ocuparam, ou repelindo-o para o sertão, os portugueses herdaram muitas das suas inimizades e idiossincrasias. Os outros, os nãotupis, os tapuias, continuaram largamente ignorados durante todo o período colonial e sobre eles corriam as lendas e versões mais fantásticas. E é significativo que a colonização portuguesa não se tenha firmado ou prosperado muito fora das regiões antes povoadas dos indígenas da língua-geral. (HOLANDA 1936, p. 77-78)

Amparando-se no estudo de Alfred Métraux sobre as migrações dos tupi-guarani, Sérgio Buarque explica a rápida conquista do litoral vinculando-a à unidade cultural e linguística dos tupis da costa. Do mesmo modo, a fronteira ocidental das terras ocupadas por esses depois de sua retirada para o sertão corresponde aproximadamente aos limites da expansão dos colonos para o Oeste a partir do século XVII. A penetração portuguesa teria se limitado às regiões de predomínio dessas culturas, o que explicaria em alguma medida o tempo muito maior que custou consolidar algum domínio sobre a região amazônica. Aparece, na observação sobre os portugueses terem herdado "muitas das inimizades e idiossincrasias" dos tupis da costa, uma curiosa brecha na orientação de absoluta primazia cultural portuguesa no período colonial, que preside a construção dos principais argumentos do livro.

Ainda mais dissonante daquela tese é o que se passa no capítulo sobre o homem cordial, para onde toda narrativa prévia parece convergir e do qual irradia a interpretação que Raízes faz da cultura brasileira. Trata-se de um tipo cujo devir social se materializa como um impulso centrífugo. Para ele, a socialização constitui "verdadeira libertação do pavor que ele sente em viver consigo mesmo", de modo que a individualidade fica reduzida a um "viver nos outros". A psicologia do homem cordial é coroada por uma citação de Nietzsche na qual o filósofo parece censurar, em seu ataque ao ideal cristão da compaixão e do amor ao próximo, a falta de amor-próprio: "Vosso mau amor de vós mesmos fez de vosso isolamento um cativeiro" (HOLANDA 1936, p. 102-103). ${ }^{4}$
4 - A passagem de Nietzsche é extraída da seção intitulada "Do amor ao próximo" do livro I de Assim falou Zaratustra. Na versão de Paulo César de Souza, "Vosso mau amor a vós mesmos transforma em prisão vossa solidão" (NIET- ZSCHE 2011, p. 60). 
Esse traço específico é bastante problemático, do ponto de vista da coerência interna do ensaio, na medida em que as enfáticas observações anteriores sobre o "personalismo" da cultura ibérica não antecipam, antes contrariam, a ideia de um "viver nos outros". As noções de personalismo e sobranceria seriam antes compatíveis, quando muito, com um "viver para (o olhar dos) outros", que seria bem diferente daquilo com que efetivamente deparamos. Na verdade, a tese da ausência de uma interioridade introspectiva no homem cordial não é remetida a alguma análise da cultura ibérica, mas sim a um ensaio crítico de D. H. Lawrence sobre a literatura norte-americana, no qual Sérgio Buarque se baseia para afirmar, com certa liberdade, que "o americano ainda é interiormente inexistente" (HOLANDA 1936 , p. 137). Esse traço seria comum, daí podemos supor, a todas as sociedades adventícias das Américas.

Nesse ponto, convém dar atenção especial às considerações que Raízes dedica à religiosidade no Brasil, porque é nessa dimensão da vida que ganham corpo alguns dos traços principais da sociabilidade e da concepção de mundo do homem cordial. É também nesse ponto que vamos encontrar uma sutil transição, na narrativa, para o tema mais caro à maioria dos comentadores de Raízes: a política. Existiria entre nós, diz o narrador, "uma religiosidade de superfície", mais atenta ao "colorido e à pompa do exterior" do que preocupada com a internalização do "sentido íntimo" das cerimônias - o que não seria de admirar, dada a ausência de "interioridade"já observada. Por mais que suas manifestações exteriores (marcadas por um acentuado sensualismo) fossem impressionantes, ela não era acompanhada de uma "moral social poderosa", pois "se perdia e se confundia em um mundo sem forma", "um culto que só apelava para os sentimentos e para os sentidos, jamais para a razão e a vontade" (HOLANDA 1936, p. 108).

Aparece aqui a imagem de um mundo sem forma, em flagrante contradição como parágrafolapidarquefecha oprimeiro capítulo. A plasticidade parece ter se espraiado insensivelmente para o âmbito da forma, subvertendo a distinção mesma entre 
formas e conteúdos (e prejudicando a integridade formal do próprio texto). É verdade que Georg Simmel, em texto de 1918 que já citamos, afirmava existir uma contradição fundamental entre forma e vida, acrescentando que, no quadro contemporâneo , despontava na cultura uma tendência hostil a toda forma como tal, o que significaria, no limite, o surgimento de um mundo sem formas (SIMMEL 1971 [1918], p. 289-293). Não parece ser isso, contudo, o que se defende em Raízes, mesmo que o argumento de que o Brasil representava em sua amorfia social uma espécie de vanguarda da história pudesse ser contemplado pela sociologia simmeliana. A passagem contradiz o que se lê em página anterior do próprio texto de Raízes. O mesmo baralhamento aparece já na apresentação do homem cordial no início do capítulo, onde lemos que a cordialidade se opõe à polidez na medida em que essa separa formas de conteúdos ao criar rituais de cortesia. Enquanto a polidez se empenha em simular "manifestações que são espontâneas no 'homem cordial'", convertendo a forma viva em fórmula, numa técnica de "defesa ante a sociedade" (HOLANDA 1936 , p. 102) que é estruturante da noção de pessoa europeia, o homem cordial não antepõe nenhuma técnica de mediação entre o mundo e seu próprio "fundo emocional extremamente rico e transbordante" (HOLANDA 1936, p. 101).

O que se verifica, devemos notar, apesar da ressalva que fizemos, não deixa de ser qualquer coisa de admirável, pois a instabilidade das formas faz com que seja viável uma configuração das relações estruturantes das formas disponíveis outra que aquela inicialmente introduzida (ou seja, aquela do invasor), de modo a tornar os mecanismos culturais irreconhecíveis do ponto de vista de seu funcionamento no estágio "original", e culminando na ausência de um conceito de personalidade/individualidade digno desse nome - isto é, sob um olhar europeu. O abismo entre a noção ocidental de pessoa e sua versão transtornada/irrealizada no homem cordial é particularmente gritante, na medida em que este é vazado como que no obverso da fôrma com que Max Weber molda o calvinista ascético na Ética protestante, onde se pressupõe que exterior e interior sejam separados por uma rija couraça. 
É necessário aqui tomar uma posição diante de um ponto que anima algumas controvérsias na fortuna crítica mais recente de Raízes, a respeito da contribuição, nesse livro, da sociologia de Max Weber. São plausíveis, para dizer o mínimo, interpretações as quais, como as de Maria Odila da Silva Dias (1985; 2008), Gabriel Cohn (2002) e Waizbort e Goldfeder (2009), negam que Raízes ofereça ao leitor um estudo orientado por uma metodologia propriamente weberiana, no sentido daqueles pressupostos epistemológicos e procedimentos de indução desdobrados com coerência pelo sociólogo alemão (Cf. COHN 1979). De todo modo, como observou Silva Dias no mesmo estudo em que se ocupa de rejeitar a tese da preponderância weberiana no argumento de Raízes do Brasil, a assimilação por Sérgio Buarque de conceitos teóricos passava por atenuações historicizantes, pois sua atitude intelectual se caracterizava por uma prevenção cautelar contra generalizações e abstrações (2008, p. 335-336) - embora se deva salientar que essa postura é mais perceptível nos trabalhos de maturidade, e menos pronunciada em Raízes do Brasil, especialmente na versão de 1936. Um tratamento à altura dessa questão passaria por uma discussão mais alentada das matrizes interpretativas de Raízes e da própria sociologia weberiana, fugindo ao escopo do presente estudo. Limito-me a registrar minha impressão de que leituras mais rigorosas, como as de Cohn e Waizbort e Goldfeder, não obstante sua erudição e disciplina teórica, aplicam ao texto de Raízes um padrão de expectativas incompatível com o estilo intelectual do autor examinado, conhecido, repita-se, por sua resistência à aplicação de grandes teorias na descrição da realidade empírica e pelo caráter adaptado das apropriações que se permitia, quando elas Ihe parecessem válidas. Meu entendimento, próximo daquele proposto por Jessé Souza (1998) em artigo de tom bastante diferente de seus livros mais recentes, é que as características que definem o homem cordial espelham quase perfeitamente aquelas que Weber atribui ao calvinista no ensaio sobre a Ética protestante e o "espírito" do capitalismo, especialmente no que diz respeito à interação com o "mundo". Na análise de Weber, o calvinista forma a individualidade numa dinâmica de confronto com o mundo, 
sempre criando mecanismos de proteção e diferenciação, e numa atitude de negação dos "afetos". Desenvolve-se, assim, uma forte "personalidade", disciplinada por frequentes exercícios de auto-exame, de modo a alcançar um ideal de "constância" espiritual que a escuda de impulsos e estímulos mundanos (WEBER 2004, p. 108). Essa proteção contra os afetos é também favorecida pelo trabalho, que realiza como que sua "ab-reação" (WEBER 2004, p. 102). A ascese calvinista direciona o indivíduo para uma vida racional "no mundo, não deste mundo, não para este mundo" (WEBER 2004, p. 139). Ora, os leitores de Raízes do Brasil se lembrarão que a postura do homem cordial é diametralmente oposta, tanto na medida em que adere plasticamente ao que se encontra à sua volta, quanto em sua aversão ao trabalho e, sobretudo, no "pavor que ele sente em viver consigo mesmo", que o leva a desenvolver uma individualidade caracterizada por "um viver nos outros" (HOLANDA 1936, p. 102-103).

As consequências disso são muitas, mas, no presente momento, interessam aquelas que reverberam na vida intelectual. O pavor da solidão é também uma aversão à atividade do pensamento e produz, como alternativa ao desenvolvimento de uma reflexão própria, o vício pela apropriação do pensamento de outros, adotando "construções da inteligência" prontas que deem "repouso" à "imaginação" (HOLANDA 1936, p. 118). Não admiraria, portanto, serem os brasileiros "um povo pouco especulativo" (HOLANDA 1936, p. 151), fascinado por sistemas de pensamento que pareçam esgotar a realidade e oferecer soluções prontas para todo tipo de problemas, como o positivismo. A adesão plástica do homem cordial à matéria do mundo à sua volta, recusando todo tipo de ritualismo e formalismo, redunda, ainda, na ausência mesma de critérios básicos que regulem a relação com o conhecimento. Apesar de esse ponto não estar entre os mais claros da argumentação de Raízes, há no livro uma estreita ligação entre a plasticidade e os problemas da vida intelectual no Brasil.

O raciocínio que trai essa ligação, apesar de bastante complexo, é feito de forma sucinta. A relação que se estabelece 
entre o indivíduo e o meio em que vive não é, entre nós, normalmente a de uma "reação de defesa", o que explicaria a "antipatia instintiva pelas formas ritualísticas". No entanto, num salto argumentativo bastante arrojado, o autor irá partir dessa constatação, para propor que essa ausência de mecanismos de depuração de formas chega a prejudicar os processos de formação das representações mentais e as balizas do exercício reflexivo. Como "a vida íntima do brasileiro não é bastante coesa, nem bastante disciplinada para envolver e dominar toda a personalidade", esta é completada por uma apropriação de elementos externos ao "eu", e está, portanto, "livre [...] para se abandonar a todo o repertório de ideias e gestos que encontra em seu meio, ainda quando obedeçam ao mais rigoroso formalismo". Em consequência, "nossa assimilação desses gestos e ideias [...] tem caráter puramente mecânico" (HOLANDA 1936, p. 110).

Em Raízes, portanto, a inteligência brasileira está marcada por uma combinação de apropriação mecânica de ideias e baixa capacidade de abstração. Seria o caso de falar numa inteligência de bricoleur (Cf. LÉVI-STRAUSS 1989, p. 15-49)? O trecho que acabo de citar, que fecha o capítulo sobre "O homem cordial", e aquele que abre o capítulo seguinte ("Novos tempos") são, nesse sentido, bastante sugestivos. Na abertura do capítulo VI, o narrador se admira, afetando a distância de um estrangeiro, mas não sem alguma ambivalência, que os brasileiros que "se presumem intelectuais" tenham o costume de aderir indistintamente, sem qualquer pudor, a "doutrinas dos mais variados matizes", vindo a sustentar, inadvertidamente, "as convicções mais díspares", desde que essas se apresentem na forma de "palavras bonitas ou argumentos sedutores". Essa relação estetizante com as ideias caracterizaria "quase todos os nossos homens de grande talento" (HOLANDA 1936, p. 114).

Esse juízo é tanto mais intrigante quanto se deixa confirmar na totalidade do corpo textual que integra: conquanto apresente um conjunto de linhas gerais razoavelmente coesas, Raízes do Brasil é um livro de acentuado ecletismo teórico-metodológico, 
no qual Weber, Simmel, Nietzsche, Dilthey, Hegel, Gilberto Freyre e até mesmo Oliveira Vianna podem cada um reivindicar ascendência sobre argumentos particulares, e ainda fartamente provido de digressões sem conexão imediata com seu núcleo temático - estamos tratando de um livro que, em sua primeira edição, não chega a 200 páginas. A profusão mesma de referências mutuamente incompatíveis (isto é, segundo um padrão específico de disciplina intelectual) entretecidas numa narração que as recodifica por meio de procedimentos normalmente associados à assimilação do "historismo" (DIAS 2008, p. 335-336) parece se conformar, igualmente, com a análise da vida intelectual brasileira realizada por Sérgio Buarque. Vale pontuar que a observação de que "todos os nossos homens de grande talento são um pouco dessa espécie" (HOLANDA 1936, p. 114) não deixa de reconhecer algum mérito nesse estilo intelectual, com o qual o próprio autor poderia se identificar, ainda que procurando adotar uma distância crítica. Lendo Raízes como exemplar bem-logrado desse estilo, é possível interpretar as referências teóricas mobilizadas em não tanto como "marcos" incorporados e rigorosamente aplicados, mas como o resultado da filtragem por um estilo de pensamento que adota aqueles elementos compatíveis com diretrizes organizadoras próprias, num sistema de seleção e combinação que reproduz, no plano intelectual, uma certa "lógica do concreto". Assim, sem absolutamente descartar a validade de análises que tentam identificar nas construções analíticas do livro traduções desta ou daquela teoria, acredito que uma ênfase nesse ponto torna mais compreensíveis as idiossincrasias teórico-metodológicas do texto.

Em vista do que se vem discutindo, para fechar o círculo em torno da cordialidade, cabe revisitar os pontos principais que a aproximam da "inconstância" discutida no ensaio de Eduardo Viveiros de Castro. Nele encontramos, além de correspondências com o texto de Raízes, algo que parece ser uma afinidade eletiva com a teorização simmeliana das formas sociais, ainda que essa apresente termos e funções diferentes daqueles do antropólogo, mesmo porque ele dispõe de uma 
bagagem teórica que Sérgio Buarque não tinha como conhecer em 1936, para não falar do próprio Simmel. Para Viveiros de Castro, a explicação para o fenômeno da inconstância (alternância entre adesão entusiasmada e rejeição ou desfiguramento do pensamento europeu) não deveria ser buscada no plano dos "conteúdos ideológicos", mas sobretudo naquele das "formas socialmente determinadas de (auto-) relação com a cultura ou tradição, de um lado, e naquele das estruturas (culturais) de pressuposição ontológica, de outro". Desse modo, a cultura não deveria ser pensada como um "sistema de crenças", mas como "um conjunto de estruturações potenciais da experiência, capaz de suportar conteúdos tradicionais variados e de absorver novos", ou seja, um "dispositivo culturante ou constituinte de processamento de crenças". Mais interessante do que observar a disposição desses conteúdos na "cultura estruturada" seria, então, perguntar pelas "condições que facultam a certas culturas atribuir às crenças alheias um estatuto de suplementaridade ou de alternatividade em relação às próprias crenças" (VIVEIROS DE CASTRO 2003, p. 209).

A discussão de "O mármore e a murta" gira, para usar os termos da leitura de Raízes por Oswald, em torno do contraponto entre agressividade e cordialidade na Weltanschauung ameríndia. É aliás curioso que o antropólogo tenha se referido algo desdenhosamente a Sérgio Buarque como um autor "politicamente correto", provavelmente inspirado pelo perfil marmóreo que lhe esculpiu certa tradição uspiana, precisamente nesse admirável estudo onde talvez viesse a calhar uma consideração da cordialidade. Ali, o índio parece ideologicamente dócil a um primeiro exame pelos adventícios, mas sua receptividade ao saber europeu acaba por se revelar ilusória. A adoção de conteúdos do cristianismo se inseria numa cosmovisão que tinha a guerra em seu centro e cuja forma permanecia intacta. Assim, sempre que tais conteúdos entrassem em contradição com as formações estruturantes do sistema de crenças originário, podiam ser descartados ou descaracterizados, pois a "crença", nesse quadro, se dava num universo de atitudes mentais que desconhecia a submissão a uma doutrina mais ampla de organização da vida (o "crer" como 
"obedecer"; a obediência como contrapartida da expectativa de salvação) - daí a especial insistência, entre os tupinambás, em continuar praticando a antropofagia e o combate aos inimigos, mesmo quando já não oferecessem resistência ostensiva aos evangelistas e às armas dos portugueses. $O$ índio se convertia, se bem que a seu modo. De modo análogo, o homem cordial combina ideias incompatíveis do ponto de vista do pensamento europeu, entre cujos axiomas destacam-se exigências de inteireza e coerência. Podemos dizer que o antropólogo atribui aos tupinambás uma plasticidade semelhante àquela que em Raízes é conferida aos portugueses. Será, porém, que o lado forte da plasticidade, elemento central da cordialidade (justamente aquele responsável pela tragédia da cultura que se apresenta nos capítulos finais do livro), deve mesmo ser procurado entre os portugueses, como queria Sérgio Buarque? Poderia a analogia estrutural entre a cordialidade e o estilo de pensamento ameríndio ser mais que mero acaso?

Não me parece absurdo imaginar que a prodigiosa plasticidade portuguesa, responsável pela "experiência sem símile" (HOLANDA 1936, p. 3) que é o Brasil, possa ter sido encontrada na projeção espelhada que a inconstância da alma selvagem impunha à ação dos colonizadores nos compromissos a que eram obrigados nas tentativas de policiar 0 gentio. Será que, pretendendo se valer de Anchieta, Vieira, Cardim, Thevet e Abbeville como meras fontes, Raízes não corria o risco de se deixar catequizar pela ideologia indígena, numa admirável vingança inadvertida do nativo? Aliás, não poderia isso ter mesmo ocorrido em alguma medida com os próprios cronistas? Nesse caso, o estilo de pensamento do nativo se veria agora regurgitado e recodificado numa interpretação que pretendia atribuir a seu algoz um protagonismo exclusivo na história nacional. Aproveitando aqui uma provocação de Eduardo Viveiros de Castro, o fato é que alguém, forçosamente, precisava se converter.

Convém notar ainda que um dos principais adendos da edição de 48 é uma longa nota sobre o uso da língua geral em São Paulo, 
centro da civilização híbrida e fronteiriça que passa, a partir dos anos 1940, a ser o interesse principal de Sérgio Buarque, como se pode verificar em Monções e Caminhos e fronteiras.

Essa mudança de foco tem a ver com um desejo, por parte de Sérgio Buarque, de compreender processos de mudança cultural, atrelado, como observou Robert Wegner, a uma reorientação fundamental nos interesses do autor. Depois de realizar em Raízes uma historiografia da permanência de formas sociais antigas, Sérgio estaria, na esteira do fim do Estado Novo e do início da experiência democrática que duraria até 1964, se voltando para processos mais dinâmicos, identificados com a democracia (Cf. WEGNER 2016) e mesmo com o capitalismo, cuja variante brasileira poderia encontrar uma certa "utopia" fundadora própria em episódios como as monções do Cuiabá e a expansão paulista. Nesses novos estudos, ganhava relevo o surgimento de valores mais afinados com a modernização da economia (Cf. RODRIGUES 2008). Assim, a conquista do Oeste pelos paulistas se apresentava como uma "raiz" mais compatível com a modernidade. Note-se aqui que, de par com nossa análise, essa preocupação de compatibilidade com o moderno comparece com muito mais força a partir da segunda edição de Raízes, como mostraram mais recentemente os trabalhos Waizbort (2011) e da Mata (2016), e é nela que verificamos a incorporação das pesquisas do autor sobre a cultura paulista, como a nota sobre a língua geral. Nesse contexto, o saber indígena aparece para dar conta da adaptação da cultura adventícia ao novo meio, embora a ênfase recaia quase sempre sobre a "cultura material" (FRANÇOZO 2007; BLAJ 1998). Mas essas observações não dizem diretamente respeito à argumentação deste texto, a não ser que pretenda inserir a atração de Sérgio pelo tema da fronteira no quadro da caracterização do homem cordial como um bricoleur ideológico, ou seja, compreendendo esse interesse como expressão de um estilo de pensamento em constante necessidade de interação com unidades estranhas ao seu interior. Salvo nesse caso, o que proponho é que o máximo de "inconstância" se encontra no Sérgio Buarque de 1936, e que o próprio autor trabalha, nas 
edições subsequentes e em outras obras, para se conformar a um estilo de pensamento e metodologia menos "selvagem" (como, de resto, avalia boa parte de seus leitores). Aí está, por sinal, uma chave de leitura para a "conversão" de Sérgio Buarque de "ensaísta" em "historiador".

Voltando à hipótese de aproximação entre cordialidade e o pensamento ameríndio, se considerarmos a mentalidade "vegetal" analisada por Viveiros de Castro, podemos argumentar que o mecanismo do homem cordial só se torna viciado quando a plasticidade se deixa enrijecer, dando lugar a traços culturais tipicamente atribuídos, justa ou injustamente, ao português: o bovarismo e a melancolia. A realidade se torna então "a triste realidade" (HOLANDA 1936, p. 124), como Sérgio lembra sobre os discursos políticos de nosso século XIX, e a filosofia, em Almeida Garrett e depois Machado de Assis, a vã filosofia. Não é que o português não seja culturalmente versátil, apenas sua versatilidade é a de uma dobradiça, mecânica - talvez por conta daquele "pedestre realismo" comentado em Visão do paraíso e que, pouco imaginoso, enrijece as formas com "atenuações plausíveis" - ao passo que a voracidade ideológica do gentio, a estar correta a hipótese de "O mármore e a murta", opera de modo vegetal, orgânico. Afinal, o objetivo das concessões técnicas (para conquistar o sertão) e ideológicas (para catequizar) que o português faz ao pensamento indígena é prático (do ponto de vista a partir do qual o ocidente concebe a razão prática, é claro), ao passo que o índio pretende, ao absorver o saber europeu, incrementar seu próprio estatuto ontológico: tendo deduzido da superioridade técnica do português a possibilidade de que ele tivesse acesso a outro mundo, ele se dispõe prontamente a aderir a sua cosmologia sem, no entanto, internalizar a sua dimensão por assim dizer infraoperacional. $O$ acesso à Terra Sem Mal pelo saber do outro: essa, a Visão do Paraíso, vista do lado oposto (VIVEIROS DE CASTRO 2003, p. 206). Ora, não poderia haver reminiscência dessa atitude mental no poder quase mágico que o homem cordial e seus descendentes atribuem aos sistemas ideológicos de países mais prósperos, se deixando seduzir pelo liberalismo, 
"com suas maiúsculas impressionantes" (HOLANDA 1936, p. 122)? Não haveria algum resquício da reverência tupi pelos "senhores da fala" (VIVEIROS DE CASTRO 2003, p. 210) na afetação bacharelesca de erudição típica do beletrismo nacional, nas extravagâncias oratórias dos debates parlamentares, no tardio cultivo da retórica clássica em terras brasileiras? É possível ler, nesse sentido, a relação que o brasileiro mantém com as ideias descrita em Raízes do Brasil como uma espécie de cargo cult, no qual a ideologia faria as vezes dos sinais exteriores mimetizados. É curioso, aliás, que Sérgio Buarque tenha negado maior importância ao índio na sociogênese da mentalidade brasileira, se ocupando principalmente de sua contribuição técnica em Monções e Caminhos e fronteiras, ao mesmo tempo em que denunciava, na outra "ponta" da cultura, a estreiteza da imaginação do português em Visão do paraíso.

Não desejo aqui impor uma hierarquia de valor aos diferentes sistemas de pensamento, mesmo porque, se estamos considerando a problemática que anima os capítulos finais de Raízes do Brasil, é difícil imaginar que o estilo inconstante do pensamento tupinambá pudesse fundamentar qualquer organização política de tipo moderno. Apenas parece-me que o mecanismo cultural da cordialidade resulta assim mais compreensível, revelando em Oswald de Andrade um dos leitores mais argutos de Raízes. A partir do ponto de vista que vim tentando expor, quando penso na apropriação irrefletida dos conteúdos de "outras" culturas denunciada em Raízes, tendo em mente ainda a proposta oswaldiana de pensar a cordialidade como herança ameríndia e matriarcal, sou levado a suspeitar que a possibilidade mais fecunda para uma compreensão da proposta de Raízes não deve supor a substituição da "devoração" por um nacionalismo "fáustico" vertical e ensimesmado, mas justamente a renúncia a uma concepção de modernidade centrada na dureza marmórea de seus conteúdos.

Antes de concluir, gostaria de aludir a mais um trecho de "O mármore e a murta" no qual convergem, com especial felicidade, Raízes, a leitura de Oswald e a tese de Viveiros de Castro. "A 
religião tupinambá", escreve o antropólogo, "projetava uma forma onde o socius constituía-se na relação ao outro, onde a incorporação do outro dependia de um sair de si - o exterior estava em processo incessante de interiorização, e o interior era não mais que um movimento para fora". Aquela sociedade "não existia fora de uma relação imanente com a alteridade". No núcleo do pensamento tupinambá estava a afirmação de "uma incompletude ontológica essencial", não apenas da sociedade, mas da "humanidade em geral" - uma incompletude da condição humana. Nessa ordem mental, "o interior e a identidade estavam hierarquicamente subordinados à exterioridade e à diferença, onde o devir e a relação prevaleciam sobre o ser e a substância" (VIVEIROS DE CASTRO 2003, p. 220).

Em que pese a tônica de grande parte da fortuna crítica em compreender a questão do atraso em suas dimensões institucional, política e econômica, Raízes do Brasil é, em primeiro lugar, uma consideração das possibilidades da autodeterminação espiritual da cultura brasileira. Na página de abertura do ensaio, lemos que "antes de investigar até que ponto poderemos alimentar no nosso ambiente um tipo próprio de cultura, cumpriria averiguar até onde representamos nele as formas de vida, as instituições e a visão de mundo de que somos herdeiros" (HOLANDA 1936, p. 3). A resposta que o livro dá nos capítulos finais a essa pergunta fundamental, baseada no que o autor percebe como uma trágica tendência à cópia mecânica de ideias estrangeiras, é pessimista. Isto, é claro, se devêssemos tomar a obra como "estátua de mármore". Dar consequência a sua possível atualidade dependeria, me parece, de uma disposição de leitura mais atenta ao que podem vicejar as suas insubmissas raízes.

\section{REFERÊNCIAS}

ANDRADE, Oswald de. A crise da filosofia messiânica. In: A utopia antropofágica. São Paulo: Globo; Secretaria de Estado de Cultura, 1990a [1950], p. 101-155. 
ANDRADE, Oswald de. Um aspecto antropofágico da cultura brasileira: o homem cordial. In: A utopia antropofágica. São Paulo: Globo; Secretaria de Estado de Cultura, 1990b [1950], p. 157-159.

ARAÚJO, Ricardo Augusto Benzaquen de. Sobrados e Mucambos e Raízes do Brasil. In: MIRANDA, Maria do Carmo Tavares de (org.). Quem somos nós? 60 anos sobrados e mucambos. Recife: Massangana, 2000. p. 35-46.

BASTOS, Elide Rugai. Raízes do Brasil - Sobrados e mucambos: um diálogo. Perspectivas (UNESP), v. 28, p. 19-36, 2005. Disponível em: https://periodicos.fclar.unesp. br/perspectivas/article/view/13/6. Acesso em: 19 fev 2019.

BASTOS, Elide Rugai. Um livro entre duas constituintes. In: HOLANDA, Sérgio Buarque de; MONTEIRO, Pedro Meira (org.); SCHWARCZ, Lilia Moritz (org.). Raízes do Brasil. Edição crítica. São Paulo: Companhia das Letras, 2016, p. 405-410.

BLAJ, Ilana. Sérgio Buarque de Holanda: historiador da cultura material. In: MELO SOUZA, Antonio Candido de (org.). Sérgio Buarque de Holanda e o Brasil. São Paulo: Fundação Perseu Abramo, 1998. p. 29-48.

BOTELHO, André; BRASIL Jr., Antonio. Primos entre si? Rural e urbano em Raízes do Brasil e Populações meridionais do Brasil. In: HOLANDA, Sérgio Buarque de; MONTEIRO, Pedro Meira (org.); SCHWARCZ, Lilia Moritz (org.). Raízes do Brasil. Edição crítica. São Paulo: Companhia das Letras, 2016. p. 411-417.

CASTRO, Conrado Pires de. A "eterna juventude" de um clássico. In: HOLANDA, Sérgio Buarque de; MONTEIRO, Pedro Meira (org.); SCHWARCZ, Lilia Moritz (org.). Raízes do Brasil. Edição crítica. São Paulo: Companhia das Letras, 2016. p. 419-429. 
COHN, Gabriel. Crítica e resignação. Fundamentos da sociologia de Max Weber. São Paulo: T. A. Queiroz, 1979.

COHN, Gabriel. O pensador do desterro. Folha de São Paulo, 23 jun 2002, s. p. Disponível em: https://www1. folha.uol.com.br/fsp/mais/fs2306200207.htm. Acesso em: 06 mai. 2019.

DIAS, Maria Odila Leite da Silva. Sérgio Buarque de Holanda, historiador. In: DIAS, Maria Odila Leite da Silva. Sérgio Buarque de Holanda. História. São Paulo: Ática, 1985, p. 7-64.

DIAS, Maria Odila Leite da Silva. Negação das negações. In: MONTEIRO, Pedro Meira; EUGÊNIO, João Kennedy. (Orgs.). Sérgio Buarque de Holanda. Perspectivas. Campinas: Unicamp; Rio de Janeiro: UERJ, 2008. p. 317-347.

EUGÊNIO, João Kennedy. Ritmo espontâneo: Organicismo em Raízes do Brasil de Sérgio Buarque de Holanda. Teresina: UFPI, 2010.

FELDMAN, Luiz. Clássico por amadurecimento. Estudos sobre Raízes do Brasil. Rio de Janeiro: Topbooks, 2015.

FRANÇOZO, Mariana. Os outros alemães de Sérgio: etnografia e povos indígenas em Caminhos e fronteiras. Revista Brasileira de Ciências Sociais, v. 22, n. 63, fev. p. 137-152, 2007. Disponível em: http://www.scielo.br/pdf/ rbcsoc/v22n63/a11v2263.pdf. Acesso em: 9 mai 2019.

FREYRE, Gilberto. Casa-grande \& senzala. Formação da família brasileira sob o regime patriarcal. São Paulo: Global, 2006 [1933].

HOLANDA, Sérgio Buarque de. Raízes do Brasil. Rio de Janeiro: José Olympio, 1936.

HOLANDA, Sérgio Buarque de. Tentativas de mitologia. São Paulo: Perspectiva, 1979. 
HOLANDA, Sérgio Buarque de. Monções e capítulos de expansão paulista. São Paulo: Companhia das Letras, 2014 [1945].

HOLANDA, Sérgio Buarque de. Caminhos e fronteiras. São Paulo: Companhia das Letras, 2017 [1957].

LÉVI-STRAUSS, Claude. 0 pensamento selvagem. Campinas: Papirus, 1989 [1962].

MATA, Sérgio da. Tentativas de desmitologia: a revolução conservadora em Raízes do Brasil. Revista Brasileira de História, v. 36, n. 73, p. 63-87, 2016. Disponível em: http://www.scielo.br/pdf/rbh/2016nahead/1806-9347-rbh2016v36n73-005.pdf. Acesso em: $1^{0} \mathrm{dez} 2018$.

MELO, Alfredo Cesar. Mudanças em ritmo próprio. In: HOLANDA, Sérgio Buarque de; MONTEIRO, Pedro Meira (org.); SCHWARCZ, Lilia Moritz (org.). Raízes do Brasil. Edição crítica. São Paulo: Companhia das Letras, 2016. p. 449-455.

MONTEIRO, Pedro Meira. Raízes rurais da família brasileira: Sérgio Buarque de Holanda e Gilberto Freyre. In: MONTEIRO, Pedro Meira. Signo e desterro. Sérgio Buarque de Holanda e a imaginação do Brasil. São Paulo: Hucitec, 2015. p. 55-77.

MONTEIRO, Pedro Meira; SCHWARCZ, Lilia Moritz. Introdução - Uma edição crítica de Raízes do Brasil: o historiador lê a si mesmo. In: HOLANDA, Sérgio Buarque de; MONTEIRO, Pedro Meira (org.); SCHWARCZ, Lilia Moritz (org.). Raízes do Brasil. Edição crítica. São Paulo: Companhia das Letras, 2016. p. 11-26.

NIETZSCHE, Friedrich. Segunda consideração intempestiva. Da utilidade e desvantagem da história para a vida. Rio de Janeiro: Relume Dumará, 2003 [1874]. 
NIETZSCHE, Friedrich. Assim falou Zaratustra. São Paulo: Companhia das Letras, 2011 [1885].

RODRIGUES, Henrique Estrada. Os sertões incultos e o ouro do passado. In: EUGÊNIO, João Kennedy; MONTEIRO, Pedro Meira (Orgs.). Sérgio Buarque de Holanda: Perspectivas. Campinas: Unicamp; Rio de Janeiro: UERJ, 2008, p. 63-82.

RODRIGUES, Henrique Estrada. Uma história cordial. In: SILVA, Ana Rosa Cloclet da; NICOLAZZI, Fernando; PEREIRA, Mateus. Contribuições à história da historiografia luso-brasileira. São Paulo: Hucitec, 2013. p. 309-321.

SOUZA, Jessé. A ética protestante e a ideologia do atraso brasileiro. Revista Brasileira de Ciências Sociais, v. 13, n. 38, p. 97-116, out. 1998. Disponível em: http://www.scielo. br/pdf/rbcsoc/v13n38/38jesst.pdf. Acesso em: $1^{0}$ dez 2018.

SIMMEL, Georg. The Conflict in Modern Culture. In: SIMMEL, Georg (org.). On individuality and social forms. Chicago: Chicago University Press, 1971 [1918]. p. 274-293.

VIVEIROS DE CASTRO, Eduardo. O mármore e a murta: sobre a inconstância da alma selvagem. In: VIVEIROS DE CASTRO, Eduardo. A inconstância da alma selvagem. São Paulo: Cosac Naify, 2003. p. 183-264.

WAIZBORT, Leopoldo. O mal-entendido da democracia. Revista Brasileira de Ciências Sociais, v. 26, n. 76, p. 39-63, 2011. Disponível em: http://www.scielo.br/pdf/ rbcsoc/v26n76/03.pdf. Acesso em 1 dez 2018.

WAIZBORT, Leopoldo; GOLDFEDER, André. Sobre os "tipos" em Raízes do Brasil. Revista ieb, n. 47, p. 13-35, mar. 2009. Disponível em: http://www.revistas.usp.br/rieb/ article/view/34638/37376. Acesso em 9 mai 2019.

WEBER, Max. A ética protestante e o "espírito" do capitalismo. São Paulo: Companhia das Letras, 2004. 
WEGNER, Robert. A montanha e os caminhos: Sérgio Buarque de Holanda entre o Rio de Janeiro e São Paulo. Revista Brasileira de História, v. 36, n. 73, p. 111-133, $2016 a$.

WEGNER, Robert. Dez anos que abalaram as raízes do Brasil. In: HOLANDA, Sérgio Buarque de; MONTEIRO, Pedro Meira (org.); SCHWARCZ, Lilia Moritz (org.). Raízes do Brasil. Edição crítica. São Paulo: Companhia das Letras, 2016b. p. 471-477.

\section{AGRADECIMENTOS E INFORMAÇŌES}

\section{André Jobim Martin (iD \\ andrejmartins@gmail.com \\ Doutorando em História Social da Cultura \\ Pontifícia Universidade Católica do Rio de Janeiro \\ Rio de Janeiro - RJ \\ Brasil}

Este texto foi originalmente elaborado para discussão na mesa "Cosmologias e noções de pessoa" do VII Seminário dos Alunos do Programa de Pós-Graduação em Antropologia Social do Museu Nacional, realizado em setembro de 2018. Agradeço, pelos valiosos comentários e sugestões que recebi ao longo da escrita e revisão do texto, a Renata Sammer, Clarissa Mattos, Henrique Estrada Rodrigues, Luiz Costa Lima e às(os) pareceristas e editores de História da Historiografia; pelo financiamento, agradeço ao CNPq.

\section{RECEBIDO EM: 6/DEZ./2018 | APROVADO EM: 23/MAIO/2019}

